Pesq. Vet. Bras. 37(12):1514-1518, dezembro 2017

DOI: $10.1590 / \mathrm{S} 0100-736 \mathrm{X} 2017001200025$

\title{
Pathological and parasitological characterization of Prosthenorchis elegans in a free-ranging marmoset Callithrix geofroyi from the Brazilian Atlantic Forest ${ }^{1}$
}

\author{
Ayisa R. de Oliveira ${ }^{2}$, Emy Hiura ${ }^{3}$, Flaviana L. Guião-Leite ${ }^{3}$, Mayra C. Flecher ${ }^{2}$, \\ Fábio R. Braga ${ }^{3 *}$, Laryssa P.C. Silva ${ }^{3}$, Thiago Sena ${ }^{3}$ and Tayse D. de Souza ${ }^{2}$
}

\begin{abstract}
Oliveira A.R., Hiura E., Guião-Leite F.L., Flecher M.A., Braga F.R., Silva L.P.C., Sena T. \& Souza T.D. 2017. Pathological and parasitological characterization of Prosthenorchis elegans in a free-ranging marmoset Callithrix geofroyi from the Brazilian Atlantic Forest. Pesquisa Veterinária Brasileira 37(12):1514-1518. Laboratório de Parasitologia Experimental e Controle Biológico, Universidade Vila Velha, Vila Velha, ES 29102920, Brazil. E-mail: fabioribeirobraga@hotmail.com

Prosthenorchis elegans is an acanthocephalan intestinal parasite reported in neotropical primates. Despite parasitism by P. elegans having already been described in wild marmosets in the Brazilian Atlantic Forest, there are no reports of this infection in wild Geoffroy's marmoset (Callithrix geofroyi). The aim of this study is to report one case of $P$. elegans parasitism in a free-ranging C. geoffroyi from Brazilian Atlantic Forest in Espírito Santo state, and characterize the pathological and parasitological findings of this infection. One Geoffroy's marmoset necropsied at the Vila Velha University's Veterinary Pathology Laboratory presented intense chronic transmural ulcerative enteritis associated with twenty cylindrical helminths present in the jejunum and ileum. We can conclude that parasitism by $P$. elegans occurs in free-ranging groups of Geoffroy's marmosets. Its infection produced severe intestinal lesions even in free-ranging marmoset and therefore is a threat to this animal's survival in wildlife and can have some impact on primate conservation in the Brazilian Atlantic Forest.
\end{abstract}

INDEX TERMS: Prosthenorchis elegans, marmoset, Callithrix geoffroyi, neotropical primates, Acantocephala, parasitology, wild animals.

RESUMO.- [Caracterização patológica e parasitológica de Prosthenorchis elegans em Callithrix geoffroyi primate de vida livre da Mata Atlântica.] Prosthenorchis elegans é um acantocéfalo intestinal descrito em primatas neotropicais. Apesar do parasitismo por P. elegans já ter sido descrito de saguis da Mata Atlântica brasileira, não há relatos da infecção em saguis-da-cara-branca (Callithrix geofroyi) de vida livre. 0 objetivo deste estudo é relatar um caso de parasitismo por P. elegans em um C. geoffroyi de vida livre proveniente da Mata Atlântica brasileira no Estado do Espírito Santo e caracterizar os achados patológicos

\footnotetext{
${ }^{1}$ Received on November 1, 2016.

Accepted for publication on April 2, 2017.

${ }^{2}$ Laboratório de Patologia Animal, Universidade Vila Velha, Vila Velha, ES 29102-920, Brazil.

${ }^{3}$ Laboratório de Parasitologia Experimental e Controle Biológico, Universidade Vila Velha, Vila Velha, ES 29102-920. Schorlaship CNPq. *Corresponding Author: fabioribeirobraga@hotmail.com
}

e parasitológicos dessa infecção. Um sagui-da-cara-branca foi necropsiado no Laboratório de Patologia Veterinária da Universidade de Vila Velha, onde foi observada intensa enterite ulcerativa transmural crônica associada a vinte helmintos cilíndricos presentes no jejuno e íleo. Conclui-se que o parasitismo por $P$. elegans ocorre em grupos livres de saguis-da-cara-branca e a sua infecção leva a lesões intestinais graves; portanto, este parasita pode prejudicar a sobrevivência deste animal na vida selvagem e pode ter algum impacto na conservação de primatas na Mata Atlântica brasileira.

TERMOS DE INDEXAÇÃO: Prosthenorchis elegans, Callithrix geoffroyi, primatas neotropicais, acantocéfala, parasitologia, animais selvagens.

\section{INTRODUCTION}

The Geoffroy's marmoset (Callithrix geoffroyi) occurs originally in the Atlantic Forest of Espírito Santo, extending 
from southeast of Bahia to southeastern region of Minas Gerais state. As in other marmosets, their diet consists mainly of gum, fruit, insects and small vertebrates (Passamani \& Rylands 2000).

Prosthenorchis elegans is an acanthocephalan intestinal parasite reported in neotropical primates, such as captive C. geoffroyi (Melo 2004), captive and wild Leontopithecus rosalia (Pissinatti et al. 2007, Sales et al. 2010), captive and wild Leontopithecus chrysomelas (Pissinatti et al. 2007, Catenacci et al. 2016), captive L. chrysopygus (Pissinatti et al. 2007), captive L. caissara (Pissinatti et al. 2007), wild Callicebus cupreus (Müller et al., 2010), wild C. penicillata (Sales et al. 2010), wild C. jacchus (Sales et al. 2010), wild hybrids of Callithix sp. (Tavela et al. 2013), wild Cebus albifrons (Falla et al. 2015), wild Saguinus leucopus (Falla et al. 2015); captive S. mystax (Chen et al. 2000) and wild C. kuhlii (Catenacci et al. 2016). It is highly pathogenic, and identified as one of the major causes of death of neotropical primates in captivity (Pissinatti et al. 2007, Müller et al. 2010).

Primates, definitive hosts, are infected by eating cockroaches and beetles (e.g., Blattodea and Coleoptera), intermediate hosts, containing the larvae (Bowman 2010). Both the chronic and acute disease has been described in primates. Chronic evolution is characterized by watery diarrhea for several months, with weakness and progressive weight loss. The acute disease occurs when there is a perforation of the intestinal wall by the parasite's proboscis leading to bacterial peritonitis and sepsis (Pissinatti et al. 2007, Bowman 2010, Müller et al. 2010).

Although parasitism by $P$. elegans has already been described in other species of wild marmosets in the Brazilian Atlantic Forest (Sales et al. 2010, Tavela et al. 2013; Catenacci et al. 2016), there are no study of the helmintic fauna from free-ranging groups of Geoffroy's marmoset. In one single study regarding helmintic fauna of this species in captivity coming from animal illegal trafficking, Melo (2004) reports the presence of $P$. elegans in less than $4 \%$ $(2 / 52)$ of these animals. Therefore, this study aims to report a case of $P$. elegans parasitism in a free-ranging C. geoffroyi from Brazilian Atlantic Forest, and characterize the pathological and parasitological findings of its infection.

\section{MATERIALS AND METHODS}

An adult Geoffroy's marmoset weighing $300 \mathrm{~g}$ was send to the Vila Velha University's Veterinary Hospital (Hvet-UVV), after been attacked by a dog. Physical exam revealed perforations in the chest and dyspnea. However, the animal died before any treatment could be implemented and was sent directly to necropsy.

For histopathological evaluation, organ fragments were collected and fixed in $10 \%$ buffered formaldehyde solution for subsequent routine histological processing. All parasites were collected and also fixed in 10\% buffered formaldehyde solution for histopathological processing and for parasitological analysis. Parasites were described morphologically for taxonomy according to Machado-Filho (1950).

\section{RESULTS}

At necropsy of the Geoffroy's marmoset were found, trauma lesions secondary to the dog attack were represented by complete perforation through the skin and intercostal muscle into the thoracic cavity, of about $0.4 \mathrm{~cm}$ in diameter associated with extensive subcutaneous hemorrhage and edema. There was moderate amount of bloody fluid in the thoracic and peritoneal cavities (Fig.1). The lung was diffusively blackened, hypocrepitant with moderate amount of bloody fluid flowing when cut and in the trachea, multifocal ecchymotic areas in the stomach and intestinal serosa, along with small lacerations in liver.

The small intestine was distended in jejunum and ileum with the presence of yellowish, soft and circular multifocal transmural nodules with approximately $0.5 \mathrm{~cm}$ in diame-

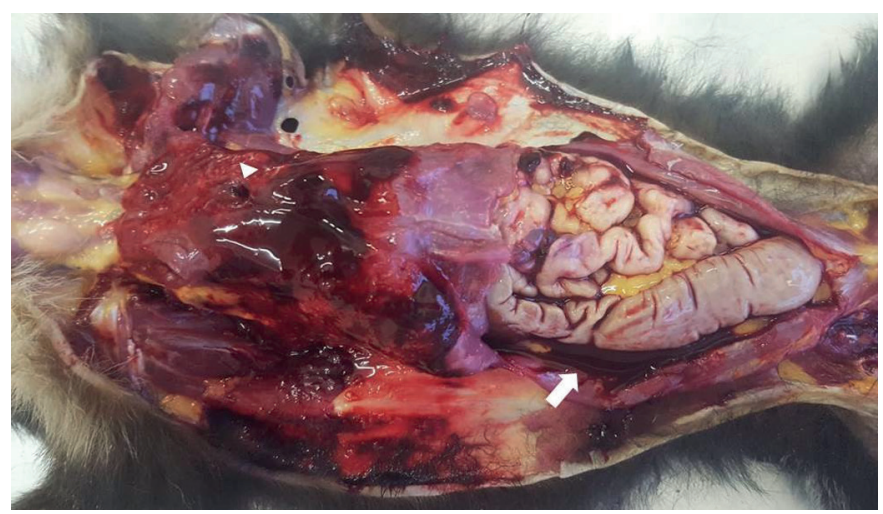

Fig.1. Severe hemorrhagic edema in the subcutaneous tissue with chest perforation (arrow head) and moderate amount of bloody fluid in peritoneal cavity (arrow) of Geoffroy's marmoset.
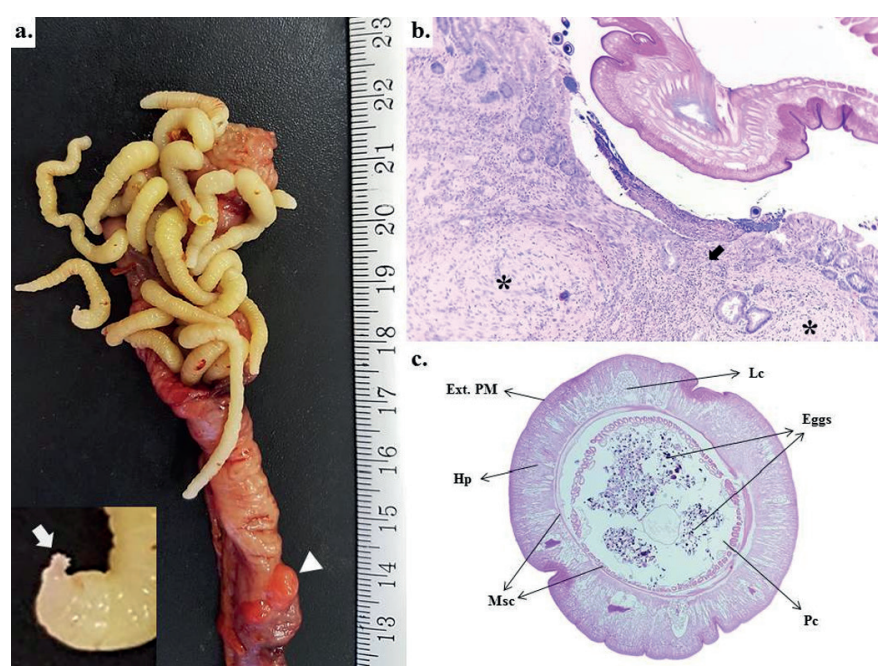

Fig.2. (a) Jejunum and ileum of Geoffroy's marmoset. Large amount of cylindrical parasites adhered to the intestinal mucosa and in the serosa yellowish nodules are observed (arrow head). In the left corner image, the detail of the proboscis (arrow) can be observed with its aspect similar to a crown, characteristic for Prosthenorchis elegans. (b) Ileum, the region where the parasite adheres to the intestinal mucosa resulting in moderate inflammatory infiltrate (arrow) can be observed, and large areas of fibroblast proliferation and myxoid matrix (*). HE, obj.40x. (c) Middle third transversal cut of a female $P$. elegans with identification of internal structures such as outer plasma membrane (Ext. PM), hypodermis (Hp), gaps (Lc), the muscle layers (Msc), the pseudocoelom (Pc) and free eggs in the pseudocoelom. HE, obj.40x. 
ter. The jejunum and ileum showed thickened mucosa and inside the lumen there were a large number of cylindrical parasites, with about 2 to $3 \mathrm{~cm}$ in length, adhered by proboscis to the intestinal mucosa associated with the transmural nodules (Fig.2a).

Microscopically, in lamina propria of jejunum and ileum, there was a diffuse moderate inflammatory infiltrate, predominantly histiocytic and neutrophilic, which in multiple foci extended into the submucosa, where a moderate amount of eosinophils was also observed. In the areas of parasite adhesion to the intestinal mucosa (Fig.2b), large areas of ulceration were seen in the mucosa, lamina propria and submucosa. The double muscle layer was replaced by a marked proliferation of fibroblasts and collagen, associated with moderate amounts of neutrophils, eosinophils and neovascularization. Deep in the muscular layer, around the region where the proboscis was attached, the tissue was loosely arranged, rich in fusiform to stellate cells, immersed in an amphophilic matrix, forming a myxomatous protuberance limited by serosa.

The liver had a moderate multifocal to coalescent centrolobular vacuolar degeneration associated with a mild multifocal neutrophilic infiltrate and multiple foci of hemorrhages. Extensive areas of hemorrhage in pulmonary parenchyma have also been observed, often with erythrocytes filling the alveoli complete.

The parasites collected and observed in transversal sections by histopathological examination showed no body cavity or digestive tract, however they did present a thick hypodermis filled with gaps, with a double muscle layer right below (longitudinal and circular), followed by a pseudocoelom, with a large number of developing eggs immersed in a serous fluid (Fig.2c).

A total of 20 parasites were present, twelve males and eight females. Females were generally larger than males and were $30.75 \mathrm{~mm}(26-36 \mathrm{~mm})$ long with $2.55 \mathrm{~mm}$ (2-3mm) maximum diameter. Males were 25.3mm (22$31 \mathrm{~mm}$ ) long with $2.08 \mathrm{~mm}(1.5-4 \mathrm{~mm})$ maximum diameter. The proboscis consisted of 06 layers, each with 06 hooks arranged in oblique series (Fig.3a) and is possible to observe a collar between the proboscis and the body. The eggs were oval, non-operculate, containing three envelopes and

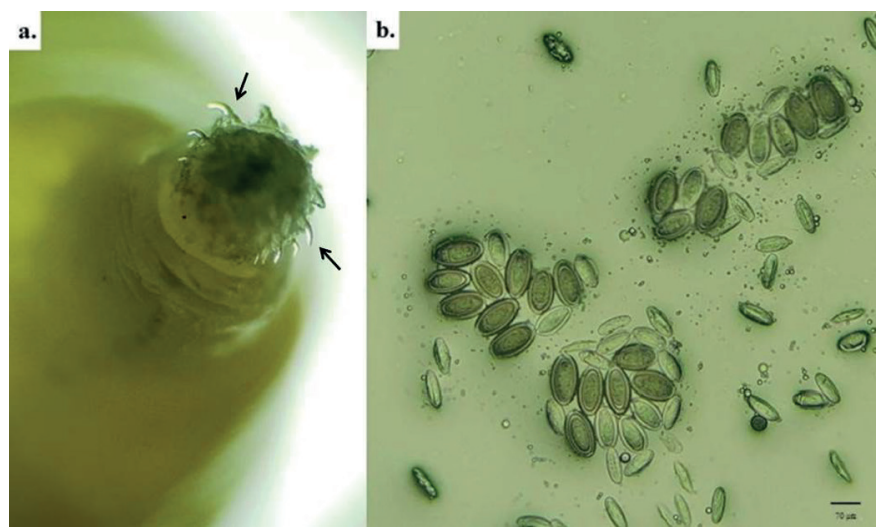

Fig.3. (a) Prosthenorchis elegans. Proboscis with hooks (arrow), connected to the body by a collar formed by the folds of the outer envelope. Obj.40x. (b) Eggs. Scale bar $=70 \mu \mathrm{m}$. the outer envelope was rugous (Fig. 3b). This morphology is characteristic of Prosthenorchis elegans (Machado-Filho 1950).

\section{DISCUSSION}

The literature describes two species of the genus Prosthenorchis parasitizing non-human primates: $P$. elegans and $P$. spirula (Pissinatti et al. 2007, Parr et al. 2013). To differentiate these two species it is necessary to examine the adult parasite about the arrangement and quantity of hooks on the proboscis (Machado-Filho 1950, Müller 2007), and the presence of a collar between the proboscis and the body in P. elegans (Machado Filho 1950).

Only the observation of the eggs in the feces is not sufficient to identify the species and the genus, since the majority of the eggs of the phylum Acanthocephala, phylum which belongs the P. elegans, are morphologically indistinguishable (Machado Filho 1950, Baker 2008). Therefore, parasitological examination of feces is a poorly accurate technique in the diagnosis of this parasite (Falla et al. 2015), which makes post-mortem diagnosis, through necropsies, an important tool for collecting data on the epidemiology of this infection.

The animal in the present case developed severe chronic transmural ulcerative enteritis caused by P. elegans. Similar lesions have been described in other primates (Pissinatti et al. 2007, Müller et al. 2010, Catenacci et al. 2016). However, in this case, besides the fibrous tissue layer adjacent to the parasite adhesion spot, described in previous studies (Pissinatti et al. 2007, Müller et al. 2010), the nodules present in these regions consisted predominantly of loosely tissue. This feature can be a predisposing factor for perforation of the intestinal wall by the parasite with abdominal cavity invasion resulting in peritonitis and sepsis reported in some cases (Melo 2004, Pissinatti et al. 2007, Bowman 2010, Catenacci et al. 2016).

The marmoset ultimately died due to respiratory failure caused by pulmonary hemorrhage and pneumothorax secondary to the chest perforation, associated with the hypovolemia due to internal bleeding from trauma. Microscopic changes in liver and lung corroborate with this diagnosis. However, is probable that the chronic intestinal disease contributed to the animal's vulnerability and greater susceptibility to dog attacks, since infected animals develop debilitating clinical signs such as weakness and abdominal pain (Pissinatti et al. 2007, Bowman 2010).

Also, the occurrence of ulcers and diffuse enteritis caused in chronic infection by $P$. elegans could reduce the digestive function of the intestine and the barrier functions against pathogens and toxins, leading to a malnutrition condition and a deficit in the organism's mechanisms defence (Müller 2007, Monteiro et al. 2010). Monteiro et al. (2010) also describe a significantly correlation between Prosthenorchis sp. infection and lower cholesterol levels, due to interference of nutrient assimilation by the intestine or to the parasite's use of the cholesterol.

In captive animals $P$. elegans quickly disseminates in the colonies due to the administration of their intermediate hosts, cockroaches and certain beetles as a dietary item 
(Pissinatti et al. 2007, Bowman 2010). In wildlife, these insects are also part of the callitrichids diet, especially when these animals inhabit peri-urban and anthropic environments, which is the case of the Geofroy's marmosets in the state of Espírito Santo (Passamani \& Rylands 2000). Wenz et al. (2010), observed a direct correlation between the increase of callitrichids (Saguinus fuscicollis and Saguinus mystax) from the rainforest of the Peruvian lowlands infected with P. elegans and the proximity to anthropic environments. Despite the wide distribution of Prosthernorchis spp. in free-living populations, when compared to captive species, it appears to be less harmful, often being an accidental finding during necropsy (Soto-Calderón et al. 2016).

The accelerated process of habitat fragmentation increases the exposure and susceptibility of wildlife fauna to parasites, since they modify important factors in parasite ecology, such as: hosts population density increment, food supply reduction, and increment in intra and interspecific interaction (Bowman 2010). The Atlantic Forest has lost more than $80 \%$ of its total coverage and is still considered one of the 34 biodiversity hotspots in the world (Ribeiro et al. 2009), being a birthplace to many neotropical primate species (IUCN 2015). Despite having a stable population until 2016 and not being considered threatened of extintion, the Geoffroy's marmoset shares its habitat with vulnerable primate species, such as the Atlantic Titi (Callicebus personatus) (IUCN 2015), facilitating the dissemination of the parasite into endangered species environment.

It is worth emphasizing that non-human primates are the alert for immediate risks of contamination in public health, since these animals are known as hosts and reservoirs of zoonoses (Verona 2008). Exemplifying this fact, the literature is vast in mentioning that the genus Callithrix, like other non-primates behave like sentinels for a range of zoonosis such as, in the present context, the yellow fever (Rocha et al., 1987). Thus, the authors of this work could not fail to discuss the correct description of parasites found in these animals and even validate that the reports are scarce.

The prevalence and abundance of parasites are factors that affect species conservation (Catenacci et al. 2016) and documenting the diversity of parasites in a free-living population is an important part of monitoring the health status of this species and the environment in which it lives (Altizer et al. 2003). Due to this fact, the study and knowledge of wild C. geofroyi parasites in Espírito Santo may collaborate in the future for the construction of an epidemiological profile of the environmental health.

Thus, the authors of the present study affirm that the present study is relevant behaving as an investigative resource, associating the parasitological research with the importance of the pathological changes (Deem et al. 2005). Acting as a possible environmental indicator of the population fragility of C. geofroyi, the report of the occurrence of P. elegans in these animals may prove to be an important tool for the diagnosis of clinical disease in endangered species.
Acknowledgements.- The authors thank CNPq and FAPES for financial support, and to Professor Filippe Elias de Freitas Soares for assistance.

Conflict of interest.- The authors declare no conflict of interest.

\section{REFERENCES}

Altizer S., Nunn C.L., Thrall P.H., Gittleman J.L., Antonovics J., Cunningham A.A., Dobson A.P., Ezenwa V., Jones K.E., Pedersen A.B., Poss M. \& Pulliam J.R.C. 2003. Social organization and parasite risk in mammals: integrating theory and empirical studies. Annu. Rev. Ecol. Evol. System. 34:517547.

Baker D.G. 2008. Biology of nematodes and acanthocephalans, p.840. In: Ibid. (Eds), Flynn's Parasites of Laboratory Animals. 2nd ed. Blackwell Publishing, Oxford, UK.

Bowman D.D. 2010. Helmintos, p.217. In: Bowman D.D. (Ed.), Georgis Parasitologia Veterinária. 9a ed. Elsevier, Rio de Janeiro. 432p.

Catenacci L.S., Colosio A.C., Oliveira L.C., De Vleeschouwer K.M., Munhoz A.D., Deem S.L. \& Pinto J.M. 2016. Occurrence of Prosthenorchis elegans in free-living primates from the Atlantic Forest of southern Bahia, Brazil. J. Wildl. Dis. 52:364-368.

Chen P.H., Miller G.F. \& Powell D.A. 2000. Colitis in a female tamarin (Saguinus mystax). Contemp. Trop. Lab. Anim. Sci. 39(2):47-49.

Deem S.L., Maisels F. \& Robbins R.G. 2005. Necropsy and parasitic findings from an adult forest buffalo (Sycerus caffer nanus) found dead in the Republic of Congo. Eur. J. Wildl. Res. 51:60-62.

Falla A., Brieva C. \& Bloor P. 2015. Mitochondrial DNA diversity in the acanthocephalan Prosthenorchis elegans in Colombia based on cytochrome c oxidase I (COI) gene sequence. Int. J. Parasitol. 4(4):401407.

IUCN 2015. The International Union for Conservation of Nature (IUCN) Red List of Threatened Species. Version 2015-4. <http://www.iucnredlist.org> Accessed June 2016.

Machado-Filho D.A. 1950. Revisão do gênero Prostenorchis Travassos, 1915 (Acantocephala). Mem. Inst. Oswaldo Cruz 48:495-544.

Melo A.L. 2004. Helminth parasites of Callithrix geoffroyi. Lab. Prim. News 43:7-9.

Müller B. 2007. Determinants of the diversity of intestinal parasites communities in sympatric New World Primates (Saguinus mystax, Saguinus fuscicollis, Callicebus cupreus). Tierärztliche Hochschule Hannover, Germany.

Müller B., Mätz-Rensing K., Yamacita J.G.P. \& Heymann E.W. 2010. Pathological and parasitological findings in a wild red titi monkey, Callicebus cupreus (Pitheciidae, Platyrrhini). Eur. J. Wildl. Res. 56:601-604.

Monteiro R.V., Dietz J.M. \& Jansen A. 2010. The impact of concomitant infections by Trypanosoma cruzi and intestinal helminths on the health of wild golden and golden-headed lion tamarins. Res. Vet. Sci. 89(1):2735

Parr N.A., Fedigan L.M. \& Kutz S.J. 2013. A coprological survey of parasites in whitefaced capuchins (Cebus capucinus) from Sector Santa Rosa, ACG, Costa Rica. Folia Primatol. Basel, 84(2):102-114.

Passamani M. \& Rylands A.B. 2000. Feeding behavior of Geoffroy's marmoset (Callithrix geoffroyi) in an Atlantic Forest fragment of south-eastern Brazil. Primatology 41:27-38.

Pissinatti L., Pissinatti A., Burity C.H.F., Mattos Jr D.G. \& Tortelly R. 2007. Ocorrência de Acanthocephala em Leontopithecus (Lesson, 1840), cativos: aspectos clínicopatológicos, Callitrichidae-Primates. Arq. Bras. Med. Vet. Zoo. 59:1473-1477.

Ribeiro M.C., Metzger J.P., Martensen A.C., Ponzoni F.J. \& Hirota M.M. 2009. The Brazilian Atlantic Forest: how much is left, and how is the remaining forest distributed? Implications for conservation. Bio. Cons. 142:141-1153.

Rocha E.M., Pereira L.H., Do Rosariom V.E. \& Krettli A.U. 1987. Experimental infections of simians with human malaria: attempts to infect Callithrix penicillata with Plasmodium falciparum. Parasitology 29:251-261. 
Sales I.S., Ruiz-Miranda C.R. \& Santos C.P. 2010. Helminths found in marmosets (Callithrix penicillata and Callithrix jacchus) introduced to the region of occurrence of golden lion tamarins (Leontopithecus rosalia) in Brazil. Vet. Parasitol. 171:123-129.

Soto-Calderón I.D., Acevedo-Garcés Y.A., Álvarez-Cardona J., Hernández-Castro C. \& García-Montoya G. 2016. Physiological and parasitological implications of living in a city: the case of the white-footed tamarin ( $\mathrm{Sa}$ guinus leucopus). Am. J. Primatol. 78:1272-1281.

Tavela A.O., Fuzessy L.F., Silva V.H.D., Junior M.C., Silva I.O. \& Souza V.B. 2013.
Helminths of wild hybrid marmosets (Callithrix sp.) living in an environment with high human activity. Revta Bras. Parasitol. Vet. 22:391-397.

Verona C.E.S. 2008. Parasitos em sagui-de-tufo-branco (Callithrix jacchus) no Rio de Janeiro. Programa de Pós-Graduação em Saúde Pública, Escola Nacional de Saúde Pública Sérgio Arouca, Fundação Oswaldo Cruz, Rio de Janeiro, 98p.

Wenz A., Heymann E.W., Petney T.N. \& Taraschewski H.F. 2010. The influence of human settlements on the parasite community in two species of Peruvian tamarin. Parasitology 137:675-684. 